China Perspectives

46 | march-april 2003

Varia

\title{
From Senior Official to Top Civil Servant
}

An Enquiry into the Shanghai Party School

\section{Emilie Tran}

\section{OpenEdition}

\section{Journals}

Electronic version

URL: http://journals.openedition.org/chinaperspectives/257

DOI: $10.4000 /$ chinaperspectives. 257

ISSN: 1996-4617

\section{Publisher}

Centre d'étude français sur la Chine contemporaine

\section{Printed version}

Date of publication: 15 April 2003

ISSN: 2070-3449

\section{Electronic reference}

Emilie Tran, «From Senior Official to Top Civil Servant », China Perspectives [Online], 46 | march-apri 2003, Online since 09 August 2012, connection on 28 October 2019. URL : http://

journals.openedition.org/chinaperspectives/257 ; DOI : 10.4000/chinaperspectives.257

This text was automatically generated on 28 October 2019

(c) All rights reserved 


\title{
From Senior Official to Top Civil Servant
}

\author{
An Enquiry into the Shanghai Party School ${ }^{1}$
}

\section{Emilie Tran}

\section{EDITOR'S NOTE}

Translated from the French original by Philip Liddell

1 The months, even more the weeks leading up to the Sixteenth Congress of the Chinese Communist Party (CCP), in the course of which were to be unveiled the names of the new leadership team, were a period that has very naturally come to be called "Pekinology". This exercise, useful though it may be, is risky. Because mistakes are never forgiven and because they are nevertheless frequent, the wealth of information required for this type of guesswork is quickly discredited. Andrew Nathan and Bruce Gilley, the "authors" of China's New Rulers: The Secret Files, a work largely based on a book published in Chinese ${ }^{2}$, have experienced this cruel reality for themselves. From the very first page, despite the brash promise of the title, the reader has to correct the stated composition of the Standing Committee of the Politburo-nine instead of seven members and Li Ruihuan's demise ${ }^{3}$-and ignore the prediction that Jiang Zemin would by now have retired completely from the political scene. Even so, the little esteem attaching to this kind of writing is a somewhat unjust, and we readily acknowledge that Pekinology, when the art is thoroughly mastered, is undeniably one of the best approaches to an understanding of the political elite and the politics of the elite ${ }^{4}$.

One can also sound out the leadership from the outside, by seeking to understand its relationship with the new society that has been created by the reforms and, in particular, its relations with the upper levels of that society. But one quickly realises that the two worlds are far from separate, their boundaries being blurred by a complex network of relationships. Individual rights still lag behind the evolution of the state; and the political system is developing even while it continues to dominate society. The 
leadership's sphere of activity is shrinking and becoming more specialised in order to respond to new tasks: thus the state broadens its mission and preserves its legitimacy. This inner evolution refocuses our analysis upon the spheres of power and invites us to approach the question of the political elite from quite another angle than that of the capital city and Zhongnanhai. The new (first) approach is different but nevertheless complementary to the old (second). In moving to the local level, we shall find that the Party schools are an excellent field for the study of these developments.

3 The shared study that we carried out within the school of the CCP Committee in Shanghai (Zhonggong Shanghai shiwei dangxiao) ${ }^{5}$ reveals that it has undergone significant changes due to the policy of reform and openness. The school was founded during the summer of 1949, just after the People's Liberation Army (PLA) had seized control of the city. It was the first of its kind and was assigned the difficult task of training the administrative staff of the new municipal government. Today, thanks to numerous measures taken by leaders at local and national level, the Shanghai Party School is fulfilling its purpose better than ever, judging by the number of officials attending the establishment and the content of the courses it offers-so much so that it has more in common with a public administration institute than a Party school.

If Party officials are being transformed into professional executives, does this mean the end of their political status? Are we on the way to seeing the Communist Party official becoming just a senior civil servant?

\section{The campus: a paradise for Party officials}

5 In 1979, China was starting out on the path to openness and economic reform. In view of the ensuing changes, the CCP's local committee in Shanghai had quickly understood that in order to manage and direct the Party officials they would need to be retrained. And even though, during the following decade, the city authorities were kept apart from the reform process, they were keen to inaugurate in their own way this new era. They decided, as early as 1983, that the Party school should be moved to a more suitable campus, one that was modern and above all more spacious ${ }^{6}$. The aim was not just to provide future officials with better training in the reforms but also to bring many more of them to Shanghai. Accordingly, new premises had to be built. The project approved by the Shanghai Communist Party in December 1983 specified that the new school and its campus should be constructed on a $200 \mathrm{mu}$ site-that is, more than 13 hectares-and that they should accommodate 1,500 trainees ${ }^{7}$. The overall budget allocated to this enterprise was to rise to 37 million yuan ${ }^{8}$. The work was begun the following year and completed in August 1987. The school moved into its new premises in July 1989.

\section{Marx, Engels and... PowerPoint: a place for study}

6 The new Party school was based at Number 200, South Hongcao Street (Hongcao nan lu), a stone's throw from the Shanghai Teacher Training College (Shanghai shifan daxue), on the south-western corner of the city, far from the centre and from the fashionable districts. It stands out against the urban landscape of this middle-class residential area.

7 The low wall surrounding the school campus and the two PLA guards posted one on each side of the entrance are there to mark the physical and symbolic divide between 
the school and the outside world: these are the chosen ones of the People's Party. For all that, this is no forbidden city of the communist age: looking from the street one can see the campus through the large entrance gates; its modern buildings rise well above the surrounding wall. Thus, the first image one has of the school is of a place intended to look open and modern, an impression confirmed as one goes through into the campus.

The entrance gates open onto a large flowerbed in the middle of which rise majestically the giant statues of Karl Marx and Friedrich Engels. By contrast, Mao Zedong and Deng Xiaoping are nowhere to be seen, whether in sculpture or in paintings. Nevertheless, when the trainees arrived back from their holidays in September 2001(for the new term), they found their school decorated with giant red banners referring to Jiang Zemin, on which they could read: xuexi Jiang zong shuji «qi yi » jianghua (Study the July 1st speech of Secretary General Jiang") and guanche "san ge daibiao" zhongyao sixiang (Apply the important ideas of the "three representations")

\section{A splendid library}

9 Behind the founding fathers of communism stands the imposing library, whose façade, all glass and steel, reflects the latest architectural trends and thus proclaims the school's will to look modern. The library's books consist mainly of works relating to human and social sciences, among them the indispensable collections of Marxist philosophy, the history of the Party, Mao's thoughts and the theories of Deng. But the latter are there more for decoration than to be consulted. Also for decoration, the floors, walls and even the lifts are clad in marble. To these "off-putting" books, as the trainee officials say themselves, they vastly prefer the periodicals hall where one can find practically all the daily papers, as well as several reviews and magazines published in China and which Party cadres do not always find within reach or which they no longer find time to read. Of the library's eight reading halls, it is the periodicals hall that is most frequented. What draws so many students to it is the opportunity offered by their time at the school to read and inform themselves about China and the contemporary world, but also to refresh their minds after classes or merely to kill time -time that some of them eventually find rather long. In addition to the publications of the People's Republic, one can also find some newspapers and magazines from Hong Kong-Wenhuibao and Jingji ribao (Economic Daily)-from Macao-Aomen ribao (Macao Daily News)-and even from Taiwan-Lianhebao (United Daily News), Zhongguo shibao (China Times) and Zhongyang ribao (Central Daily News).

Opposite the periodicals hall is one devoted to neibu documents (those restricted to internal circulation), where the trainee officials may go only after producing documentary evidence of their grade. In principle, the great majority of them are entitled to access. However, if one compares the few who consult the documents with the many who read the newspapers, one swiftly concludes that these famous documents, despite their confidential nature, do not arouse any particular interest among the trainees. When asked about this, their reply is beyond appeal: "It doesn't interest us!" Indeed, within their danwei, they have already acquainted themselves with the neibu documents relating to their administrative work. Moreover, documents that might have interested them are not to be found here or may be consulted only by a 
rather small minority of the students-and these never read them because they already know the "secrets" they contain.

11 Adjacent to the neibu documents hall is a room reserved for foreign periodicals: one must pass through the former to gain access to the latter. It goes to show that the contents of foreign publications are even more confidential than that of the neibu documents... Set out on the display stands are a review in Russian and another in Japanese as well as several daily papers and reviews in English: South China Morning Post, International Herald Tribune, Far Eastern Economic Review, Time, and even The China Quarterly. But this room is even less busy than the neibu documents hall, quite simply because few of the trainee officials master another language sufficiently well to tackle one these periodicals.

12 The other hall attracting as many, or even more, of the trainees is the multimedia centre where the fifteen or so computers are invaded whenever there are no classes. Indeed, each trainee is allocated a limited number of hours for surfing the Internet during his or her course, the quota being determined according to grade and length of course. This is how the trainees, in common with a good number of their compatriots, learned about the events of September 11th 2001 even before the Chinese media had broadcast the news. This multimedia facility has another function, its primary purpose: it is there to transmit, via the internal party schools network, certain video conference classes from the Party's Central School in Peking. Needless to say, it is not to listen to these classes-not even those given by leading figures in the prestigious Peking School -that the trainees in Shanghai flock to the computers. Most use them to check their emails or to surf the Web, generally seeking out news sites.

\section{Ultra-modern classrooms}

13 While they are not obliged to take any interest in lectures from the Central Party School, trainees do have a duty to attend those laid on by the Shanghai School to show that they have completed their courses. Classes are held in the same building, located to the right of the main entrance on the north-eastern side of the campus. Like the library, this building too is a paragon of modern architecture. Three storeys high and constructed as a rotunda, it is spacious, airy and well-lit thanks to a roof with glass openings allowing free ingress to the daylight, which is then reflected off white walls and marble. An electronic indicator board, hanging in the entrance-hall, scrolls through the different years showing, for each one, the room number for the next class. The classrooms are in keeping with the building: they are white and functional, with no decoration at all, not so much as a picture of Marx, or Mao, or even calligraphic designs -which is surprising in such a place, to say the least. On the other hand, every single classroom is equipped with Microsoft PowerPoint, enabling teachers to give multimedia presentations during their classes. The lecturers at the school comply with this practice having been trained to do so, but some are less proficient than others. Indeed, delivering one's classes with the aid of PowerPoint presentations seems to have become the defining mark of up-to-date teaching. A little electronic jingle announces the beginning and the end of each session. The only false note in this ensemble of antiseptic modernity intrudes during breaks between classes: for fifteen minutes on end, loudspeakers bellow the revolutionary songs of another age, their words clashing as discordantly with the décor as with the content of the lectures... 
Table1: Courses at the Shanghai Party scholl, 1949-1965

\begin{tabular}{|c|c|c|c|c|}
\hline Time frame & Course name & $\begin{array}{l}\text { Numbor of } \\
\text { term-groups }\end{array}$ & $\begin{array}{l}\text { Length } \\
\text { of training }\end{array}$ & $\begin{array}{l}\text { Number of } \\
\text { trainees }\end{array}$ \\
\hline $1949-1957$ & $\begin{array}{l}\text { Training course } \\
\text { Xunlian ban }\end{array}$ & 12 & $\begin{array}{l}3 \text { to } 8 \\
\text { months }\end{array}$ & 6,531 \\
\hline $1949-1954$ & $\begin{array}{l}\text { Specialised } \\
\text { training course } \\
\text { Zmuanti xunlian ban }\end{array}$ & 3 & $\begin{array}{l}2 \text { to } 5 \\
\text { months }\end{array}$ & 1,845 \\
\hline $1953-1955$ & $\begin{array}{l}\text { Cultural course } \\
\text { for cadres } \\
\text { Ganbu wenhua ban }\end{array}$ & 1 & 2 years & 157 \\
\hline $1959-1965$ & $\begin{array}{l}\text { Course on theory } \\
\text { Lilum ban }\end{array}$ & 7 & $\begin{array}{l}2 \text { months } \\
\text { to } 1 \text { year }\end{array}$ & 546 \\
\hline $1960-1963$ & $\begin{array}{c}\text { In-house training } \\
\text { course } \\
\text { Limxun bar }\end{array}$ & 10 & $\begin{array}{l}6 \text { weeks } \\
\text { to } 6 \text { months }\end{array}$ & 2.731 \\
\hline $1963-1964$ & $\begin{array}{l}\text { Course in specialised } \\
\text { research } \\
\text { Zhuanti xunvian tvan }\end{array}$ & 3 & $\begin{array}{l}2 \text { weeks } \\
\text { to } 4 \text { months }\end{array}$ & 2.188 \\
\hline Total & & 36 & & 13,998 \\
\hline
\end{tabular}

1. In this case, the courses take place during working hours.

Source: Figures compiled based on Zhonggong Shanghai shiwei dangxiao zhi, Shanghai jiaoyu chubanshe, Shanghai, 1999.

\section{Three-star hotel with swimming pool: a place to relax in}

14 Full-time trainees, that is to say, those who have classes from Monday morning until Friday lunchtime, are supposed to stay on campus throughout the week and are allowed home only at the weekend. They live on campus, which for that purpose includes a restaurant-cafeteria that serves up three meals a day, quite varied and tasty food, just like a three-star hotel, built and managed by the Jinjiang group of Shanghai. The sleeping quarters are modern and comfortable, but a little bland; the 450 rooms comprise 100 singles and 350 doubles, providing accommodation for up to 800 trainees, generally sleeping two to a room. Even if the young officials object to this lack of privacy, they readily acknowledge that having to share a room with a fellow-student in their year enables them to make connections that could ultimately be useful. Building up a network of contacts is, in most trainees' eyes, the most important aspect of their time at the school. They consider, in effect, that acquiring a rich network of guanxi is more useful to their professional career than anything they might learn in the classroom. According to one former trainee, the wish-secret-of each trainee, when sent on a training course at the school, is to be part of a year of officials that might turn out useful to know... This trainee's wish was fulfilled beyond all expectations, his former roommate being now Chief of Police in Shanghai 9 !

The other buildings on the campus-administration offices, former classrooms, a dormitory for auxiliary staff at the school-are older, strictly utilitarian in style and, to sum up, rather grim. Even so, in everyone's opinion-administrative staff, teachers, trainee officials-the campus, far removed from the noise and pollution of the city centre, is an agreeable place with its leafy walks, lawns and ornamental lakes, including 
a lily pond. Real care is taken to pamper the trainees, by offering them living standards that are modern, comfortable-even luxurious-by comparison with their backgrounds at home or at work. All those questioned admit to a slight sense of wasting their time, but otherwise they recognise that they do benefit from the course, and more particularly from the charms of the campus: they can rest from the heavy workload imposed by their many responsibilities-even though many of them continue to carry out their management duties from a distance. Indeed, a day at the school has nothing in common with the relentless rhythm of their professional lives: classes begin at 08:30 and finish at 16:00, with a two-and-a-half-hour break for lunch, siesta included! Outside teaching hours their time is free, so long as they stay on campus.

To occupy all this free time, plans are afoot to build, between now and 2005, a bowling alley and a swimming pool. Officially, the aim is to introduce physical exercise to the timetable for the courses; and, if the recreational implications of bowling and swimming help to make the campus seem like paradise and thus to make the courses all the more attractive, well, so much the better. "Healthy mind, healthy body"-as the old saying also goes in China's communist regime.

\section{Once a worker, now a dynamic young executive: recruitment criteria are becoming more elitist}

17 Between 1949 and the end of 2002, 65,000 trainees passed through the Shanghai Party School, nearly 14,000 between 1949 and 1965 and over 50,000 between 1978 and 2002: the total is arrived at by adding together the numbers of trainees as listed in tables 2, 3 and 4. Between 1966 and 1978 the school was closed. That gives us an average of 823 trainees a year before the Cultural Revolution as against 2,088 a year over the period of the reforms. So the Shanghai Party School has trained on average two-and-a-half times more officials under Deng and Jiang than during the Maoist period, a finding that is at least surprising at first sight. Indeed, one would have expected a Party school to be particularly active during the most politicised years of the regime, that is to say from 1949 until Mao's death, and to recruit fewer trainees from 1978 onwards. The Shanghai Party School was set up, like the CCP's other schools, with the primary aim of training Party officials (ganbu lunxun) ${ }^{10}$, but it also trained other socio-professional categories including people from outside the Party. The exponential growth in the number of trainees and the variation in their qualifications are simply the reflection of the Chinese Party-state's political and historical evolution since its birth.

\section{From 1949 to the Cultural revolution: the Party school mirrors the regime's fortunes}

18 The Shanghai Party School opened, from 1952 onwards, a section exclusively for workers, to teach them politics (Shanghai gongren zhengzhi xuexiao). Those who were enrolled for a course but who had not finished their schooling had to go back to school before joining the Party school. Two years later, the part of the school admitting party officials (Zhonggong Shanghai shiwei dangxiao yi bu) was separated from that admitting workers (Zhonggong Shanghai shiwei dangxiao er bu). These measures to promote the education of the working classes in an institution designed first of all for officials of the Party-state were not at all unusual in those early years of the People's Republic. Indeed, 
the new communist regime was striving to bring China in line with Marxist thinking and, to that end, it had to create its working class. The tools for this purpose were the urbanisation and industrialisation policies of the first five-year plan, which was officially launched in 1953 . We should note that in doing so, contrary to many assumptions, the regime was aiming more at politicising the whole of society than at affirming the proletarian character of the Chinese Revolution in view of its peasant reality. The politicisation of the towns (and therefore of the workers) came after that of the countryside (and therefore of the peasants). The education of the workers was approached by means of training them in class consciousness and this task was entrusted to the Party school. The 800 selected workers were able, by the end of their course, to claim the status of Party official ${ }^{11}$.

Refocusing our attention now on the first section of the Party school (Zhonggong Shanghai shiwei dangxiao yi bu) after the school for workers had broken away, its main task from 1954 onwards was to train the Party's scientific and technical officials (keji dangyuan ganbu). Here again, we can see the new regime's preoccupations, as it struggled to make up for its backwardness in matters of science and technology and to emulate the model of its big Soviet brother. Nevertheless, this section of the school was not restricted to this category of officials. At the same time, it was organising a series of "specialised training courses" (zhuanti xunlian ban) intended for a wider public. In winter 1952, it opened a course for the employees of a shipping company. In all, 1,040 merchant navy officers, during their stopover in Shanghai, did a three-month course at the school ${ }^{12}$. Then in 1954, with the renewal of the thought reform campaign, 629 officials were selected for a re-education course, of whom 242 were not Party members (fei dang ganbu) ${ }^{13}$. Aside from all these courses intended for students of varying backgrounds, the Shanghai Party School (and, for a period, its first section) did not neglect its initial mission, which was to concentrate its efforts upon officials of the administration of the Party-state: between 1949 and 1957, it trained no fewer than 7,493 officials ${ }^{14}$.

20 The ambivalent approach to the selection of trainees arises also from the fact that there was at the start no specific instruction as to the level of officials to be admitted to the various Party schools. At the end of 1954, a circular from the CCP in Peking summed up the question ${ }^{15}$. It distinguished three types of Party school, and prescribed for each of them the trainees' qualifications. At the top were the Marxism-Leninism Institutes, placed under the direct control of the Central Committee of the Communist Party (Zhonggong zhongyang zhishu malie xueyuan). These were responsible at the local level for training Party Secretaries and their deputies, civil servants entrusted with special tasks (zhuanyuan) and all other officials of equivalent level or above. To sum up, these Party schools are set aside for senior civil servants and are called upper schools (gaoji dangxiao). Next come the middle schools (zhongji dangxiao) open to Party members at the local level, to district secretaries and their deputies and to heads of districts (xian), and also to all other officials of equivalent grade. Lastly, the elementary schools (chuji dangxiao) are open to Party members at xian level, and to secretaries, deputysecretaries and heads of urban districts as well as to all officials of similar status. However, Shanghai was to apply the centre's decision only three years later, on February 8th 1957, when the two sections of the school were reunited under this new name: the Elementary School of the Committee of the Communist Party of Shanghai 
(Zhonggong Shanghai shiwei chuji dangxiao), which fell, as the name indicated, into the third category.

21 But the school had only just clarified the task allotted to it when it was confronted with a serious crisis. In April 1957, the rectification campaign broadened, with the Hundred Flowers Movement, into a national mass movement. Mao designated the officials of the Party as targets and wished them to be subjected to the "criticism of the masses". Through them, the Party schools were also affected by the shake-up within the Party and, in Shanghai, the Elementary School ceased all activity from June 13th1957 onwards. It did not open its doors again until February 1958.

In February 1959, the Elementary School merged with a middle school, thus higher ranked than itself, and took the name it had adopted when first set up in 1949-the school of the Committee of the Communist Party of Shanghai (Zhonggong Shanghai shiwei dangxiao)-a name that has remained unchanged ever since. The merger raised the establishment to the level of middle school; accordingly, the category of trainees was also raised. From then on, its role was to train officials at the level of (the) department (chu): or at equivalent levels in the organisations of the Party and the state, or within companies and enterprises, and as much at the level of the city (shi) and the urban districts as of the district. After three changes of name and ten years of indiscriminate recruitment (workers, sailors, civil servants without Party affiliation and Party officials), the Shanghai School had recovered its original name and readopted its initial task. Thus 1959 gave it a new start-but the political events of the following decade were once again to hinder its activities.

In 1962, Mao launched a second shake-up of the Party: this was the Movement for Socialist Education, which was in fact the prelude to the Cultural Revolution. Over the following two years, local officials were subjected to widespread purges. On November 21st 1963, 2,000 officials were sent to the countryside after only ten days' attendance at the school! In 1964, the school organised only one training course; and, in January 1965, all those who were finishing their courses were also sent down to the countryside with the school's Deputy Director ${ }^{16}$. The Cultural Revolution, which started in earnest that same year, was to take an extreme turn in Shanghai with the fall of its municipal government in December 1966. Then the city became a stronghold for the Gang of Four during the $1970 \mathrm{~s}^{17}$. The Shanghai Party School, which had ceased all activity from 1965, was officially closed on February 3rd 1969 and was to stay closed for the next ten years.

Between 1959 and 1964, it had organised courses for 5,465 officials ${ }^{18}$, which in relation to the 7,493 trainees of the earlier period (1949 to 1957) represents a yearly average that is comparable, even slightly higher: 832 in the first phase as against 910 in the second. Had it not been for the Cultural Revolution, the numbers of trainees would have been higher still. Twice over, in 1958 and from 1965 onwards, the school suffered the consequences of ideological and bureaucratic clashes, factional struggles that split the Party apparatus. Because of its status as Party school and, above all, because of its role, which was to train Party officials, the school's fate was intimately linked with that of the Chinese Party-state and reflected its ups and downs. Thus, throughout the 1950s, at a time when the new regime was in the process of becoming institutionalised ${ }^{19}$, the mission entrusted to the Shanghai Party School was not yet very well defined. Then, during the following decade, the decline of the Party-state apparatus impeded the school's performance and eventually brought about its closure. 


\section{8 to the present day: the Party school, protagonist of the reforms}

Mao died in September 1976. The following month, the Shanghai Gang of Four, led by Jiang Qing, were arrested. The leading officials of the city administration had to confront a similar situation to that of 1949: once it had been liberated from the radicals' grasp, the city no longer had enough officials to cope with the administration. On one hand, many of those trained during the 1960s had been sent to the countryside and, on the other, since the arrest of the Gang of Four, the municipal apparatus had been subjected to purges aimed at eliminating all its former partisans: nearly one-third of the officials were affected ${ }^{20}$. Thus, in November 1977 the question arose of reopening the Party school so that it could quickly train new officials. This was done on April 11th 1978.

This time, however, the school was no longer restricted to officials at the level of the department as had been specified at the time when its status had last been changed in 1959. It also aimed at training officers of higher grades, though precise criteria were not set. In August 1981, a new arrangement was reached: each year, the school had to devote its second semester to "the training of young elite officials" (peixun youxiu zhongqingnian ganbu) to turn them into the leading figures of the coming era. Thus, the school took a decisive turn, opening its doors now to officials with different qualifications, being both younger and better educated, hence the term "elite" (youxiu). Zhongqingnian, referred to people aged between 34 and 44 . At the end of their course, these trainees were to be promoted to the upper grades to replace the older generation, that is to say, officials over 60 who were retiring in increasing numbers ${ }^{21}$. In March of the following year, the Shanghai School adopted the policy of the "four mores" (si hua), the word "more" being applied to the qualities of the officials they aimed to turn out: more revolutionary, (geminghua), more youth (nianqinghua), more cultivated (zhishihua) and more specialised (zhuanyehua). While the first criterion is largely rhetorical, the three others imply an increasingly elitist recruitment and training policy. In renewing its officials, Shanghai wanted to show Peking not only that it was definitively moving away from its radical past but also that it was preparing its leaders fully to comprehend the reform process when its own turn should come.

For its part, the Central Committee of the CCP decided, in March 1983, that provincial leaders would have to do a course at the Central Party School ${ }^{22}$. In sending them to Peking, to the most prestigious of all the Party schools, the Chinese leaders were showing that they were intent on providing the best possible training for top provincial civil servants. Moreover, the Central Committee published a circular aimed at standardising the reforms within Party schools across the country. This document indicates that the Party schools must recruit from among officials at the level of the department (chu) and the bureau (ju); their task was to train those entrusted with political work (zhengzhi ganbu) and theoretical work (lilun ganbu); at the same time, they had to organise specialised catching up classes (zhuanxiu ke) ${ }^{23}$. This last point was in fact the most important, as it gave the local Party organisations and their schools a free hand to adapt their courses according to their own needs.

February 1984 marked a new turning point in the history of the Shanghai School. During a visit by Deng Xiaoping and Wang Zhen, who was at that time Director of the Central Party School, Wang praised the quality of the training that officials were 
receiving in Shanghai and suggested to Deng that, at the end of their courses, they should be deployed throughout China. This little suggestion was enough to raise the Shanghai School to the status of a national school, a model, in fact, to be followed, and it raised the school's prestige above that of the other provincial Party schools.

Table 2: Courses at the shanghai Party school, 1978-1998

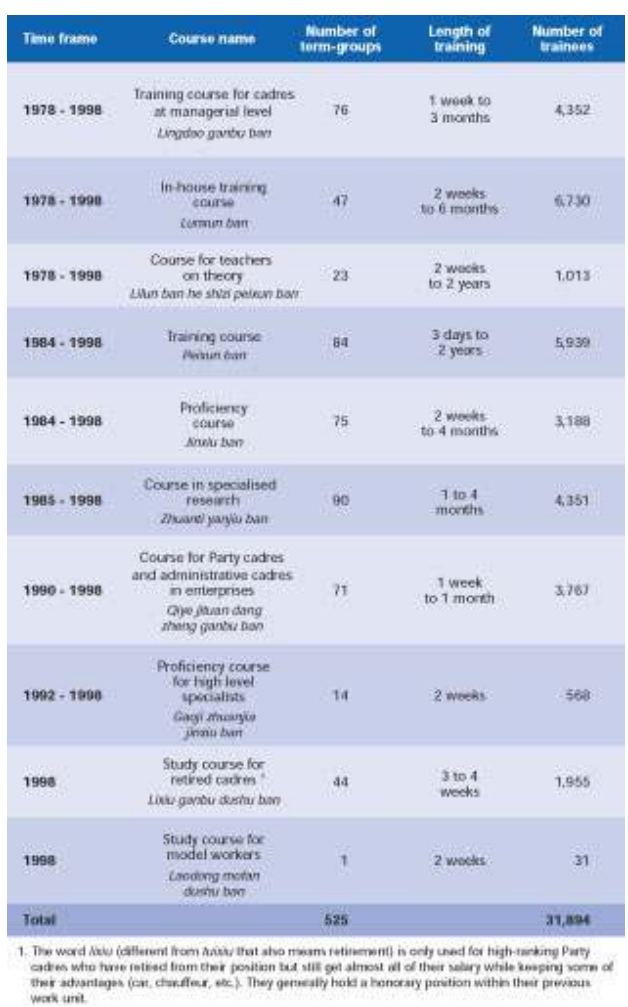

Source: Idem table 1 
Table 3: Courses at the Shanghai Administration Institute, 1985-1999

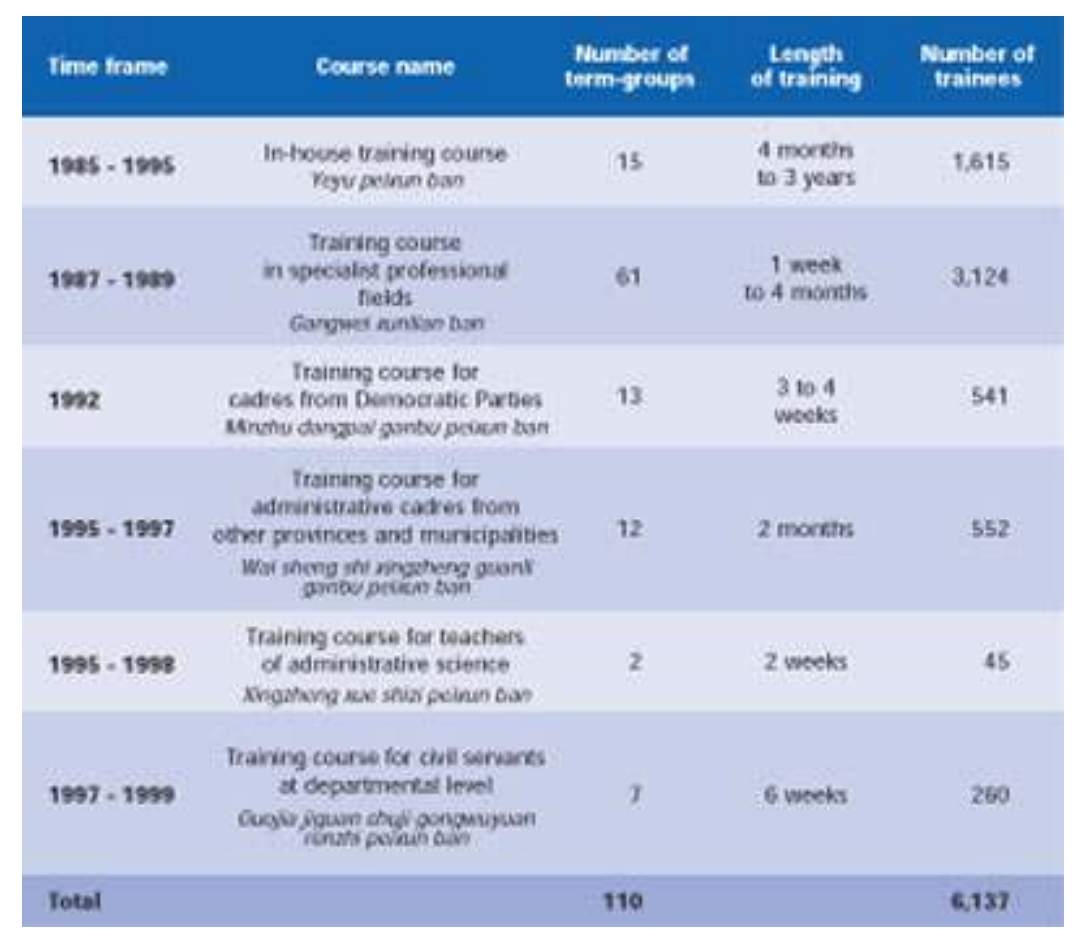

Source: Idem table 1

At that time, as the reforms took hold along with the new forms of management that they required, Chinese leaders became aware that the new elites, at local and national level, should have not merely political skills-which, broadly speaking, can be summed up as sticking to the Party line-but also skills in public administration. For this reason, in accordance with the decision by the Central Department of Organisation published in October $1983{ }^{24}$, the Shanghai Municipal administration set up its Administration Institute for Officials (Shanghai shi xingzheng guanli ganbu xueyuan) which became, in April 1989, the Shanghai Administration Institute (Shanghai xingzheng xueyuan). Straight after it was founded, it was integrated into the Shanghai Party School, sharing its premises as well as its management and administrative staff. Inscriptions were located on each side of the entrance gate: Shanghai xingzheng xueyuan, on one side, and Shanghai shiwei dangxiao, on the other: "two names for a single school" (liang kuai paizi, yi tao banzi). But this situation was not unique to Shanghai: it became the rule in all local areas that had an administration institute for it to be housed with the Party school as a single establishment. The only remaining exception was in Peking where the Central Party School (Zhonggong zhongyang dangxiao) is totally separate from the National Institute of Administration (Guojia xingzheng xueyuan).

The role of the Institute of Administration in Shanghai (see Table 3) consists in training officials responsible for public administration and, more widely, the officials of the city administration (peixun Shanghai shi xingzheng guanli ganbu he gongwuyuan). It extends to recruiting young officials of the "democratic parties" and organising special training courses for them (minzhu dangpai zhongqingnian ganbu peixun ban). It must also recruit and train officials from other provinces, in particular Yunnan and Xinjiang, because of their privileged relationships with the Shanghai city administration. These officials attend courses specially prepared for them (wai sheng shi xingzheng guanli ganbu peixun 
ban) and are ostracised to some extent, in the canteen and around the campus, by their Shanghai colleagues, who consider the visitors as country bumpkins (hen tu). By putting in place its own training courses oriented towards public administration and establishing its own trainee years whose recruitment extends beyond Party officials, the Administration Institute wishes to be separate from the Party school and to be identified as a school with a professional purpose, one beyond political considerations and regional splits. It also seeks to open itself to the outside world by inviting lecturers from abroad and developing exchange programmes with European and American administration institutes, among them the French École Nationale d'Administration (ENA). The Shanghai Institute of Administration is therefore the local administration's instrument of reform ${ }^{25}$.

31 Moreover, the policy of reform and openness has made Chinese leaders aware that it is just as important to train the officials who find themselves running the state enterprises. For this reason, ever since 1990, the school has been organising training courses specially tailored for administration and Party officials in enterprise groupings (qiye jituan dangzheng ganbu ban). Between 1990 and 2002, the school turned out nearly 4,000 trainees in this category. These courses were intended for officials in the big state groupings, particular the enterprises in Shanghai and its surrounding region, such as Baoshan.

32 Even when it comes to selecting its trainees, the Shanghai Party School works in close collaboration with the Shanghai City Bureau of Human Resources (Shanghai shi renshi ju) since this is the office that has all the career data, not just those of Party officials but also of all the civil servants employed by the local Party-state apparatus. The Human Resources Bureau draws up the list of officials and civil servants whose turn it is to do a course at the Party school; a candidate is chosen either by virtue of his or her personal record or because the Bureau is carrying out the directives of the Party's local committee which decides to organise specific training courses according to current circumstances-for instance, on the occasion of China's accession to the World Trade Organisation or to study the political slogans currently on the agenda, such as the Theory of the Three Representations. But it can happen that some administrations decide for themselves to call on the Party school and its Administration Institute to organise a one-off course adapted to its needs.

33 Thus, the Shanghai Party School, responding to an initiative dictated by the need to make up the shortage of officials-therefore quantitative in kind-has undertaken reforms of a more qualitative kind; it has taken on the role of training the new leadership elite, made up of younger and more competent officials within both the Party-state apparatus and the economic structures that it directly manages. But have these reforms favoured the modernisation of the Shanghai Municipal administration?

Since the school reopened in 1978, the combination of measures described above has been aimed at redefining and making more professional the job of Party official or civil servant. From this point of view, one may effectively speak of the Shanghai administration going through a form of modernisation. On the other hand, the fact of having within one single entity the Party school and the Administration Institute is highly significant. If the reforms introduced at the local level, in a city that sees itself as China's economic and financial capital as well as its shop window, are not aimed at a separation-at least relative-between state administrative structures and the Party apparatus, then how can this be an objective at the national level? The reforms within this Party school reflect the concerns and the limitations of the political reforms as a 
whole: the modernisation of the administration, and the professionalisation of management staff are accepted facts and recognised norms, but only within the Partystate and under its control: these remain omnipresent. One might conclude that this requirement restricts the reach of any reform. Conversely, however, bearing in mind that the leadership persists in holding onto structures that are evolving, sometimes quite considerably, is it not exposing itself to unwanted change that, through force of circumstances, might take effect from within?

The last reform to affect the trainees, adopted on May 5th 1990, shows what is at stake in this two-sided reality. The local authorities decided then that all officials at bureau level (ju) must return for a course at the Party school every three to five years ${ }^{26}$; this would help them to bring their knowledge up to date and to remain in step with the progress of the reforms. So here, reaffirmed, is the school's concern-following the creation of its Administration Institute-to continue working towards making Party officials more professional. It turned out, however, that this new rule had another use, that of assuring the Party school that it would always have trainees within its walls, which offers a double advantage. Firstly, the school is guaranteed a continuous supply of funds, since the danwei have a duty to pay the training expenses (xuefei) of their employees, who are themselves obliged to follow the courses; these expenses are calculated in thousands of yuan. Thus, a full-time course lasting three months costs about 6,000 yuan per head. Secondly, this measure enables the regime regularly to remind its officials of the Party line and to exert its power directly. It may punish them (why?) by holding back promotion or even by demoting them-though this is rare; or it may reward them with a promotion at the end of the training course. To sum up, the Chinese Party-state takes a payoff from the principles of its own structure so as to maintain its domination over its leading officials.

\section{Classes in the spirit of the times}

Even though the Shanghai Party School is wielded like an instrument by the Chinese communist regime, which uses it to control its personnel, it is above all, as its name indicates, a school: that is to say, "an establishment in which collective education is offered" ${ }^{27}$. And, effectively, the main activity of the officials enrolled in a training course is to follow the classes that make up the main part of the timetable.

If the trainees have evolved both quantitatively and qualitatively, the same is true of the courses. They have grown in number: before the Cultural Revolution there were five types of course (Table 1), whereas since 1979 there have been 16, of which ten are offered by the Party school (Table 2), and six by the Administration Institute (Table 3). Aside from the different names given to these courses, their programmes of study, that is to say, the number of classes and the subjects taught, do not vary much from one course to another over a given period. Between 1949 and 1965, for example, the officials taking part in the "specialised training course" followed more or less the same course syllabus as did those enrolled for the "theoretical course". On the other hand, the content of the "training course" during the period 1949 to 1956 is no longer anything like that of the "training course" today. So the content of the courses evolves with time; and in this respect they reflect-just like the qualifications of the trainees, but perhaps even more obviously-the upheavals that the People's Republic has lived through since 1949 and still more since 1979. 


\title{
From Marxism...
}

\begin{abstract}
a theoretical nature, in the other. A course's syllabus may be composed of a single kind of class or of two kinds. Between 1949 and 1965, 6,392 trainees took practical classes during their courses. By "laying end to end" the duration of the courses, this was a total 49 months of training, that is to say, more than four years. For this same period, 12,078 trainees qualified for theoretical classes during their courses and between them spent 249 months in training, more than twenty years ${ }^{28}$. Admittedly, this type of calculation, because of the lack of precise data on the number of hours spent in each class, must be used with caution. Nevertheless, it does give some indication of the place occupied by these two kinds of classes in course syllabuses before the Cultural Revolution. We may thus retain the fact that, between 1949 and 1965, the theoretical classes drew twice as many trainees as the practical classes for a training duration five times as long!
\end{abstract}

arranged within two categories: courses with a practical purpose, in one, and courses of

Table 4: Number of trainees, 1999-2002

\begin{tabular}{|ccc|} 
& Party School & Administration Institute \\
\hline 1999 & 1,500 & 500 \\
2000 & 2,000 & 800 \\
2001 & 2,300 & 1,000 \\
2002 & 2,500 & 1,500 \\
\hline
\end{tabular}

Source: Idem table 1

The practical classes are those that have an immediate application, because they have a bearing either on questions of public administration or on the introduction of specific policies. From 1949 until the school was closed, 4,985 trainees took classes on the new administration of the City administration, for a total duration of nearly four years. In 1953, with the launch of the first five-year plan, 1,407 trainees, whose training totalled three months, took classes specifically on the introduction of planning.

The courses of a more theoretical kind covered three main areas of study: the Chinese Communist Party, socialism and the reading of texts. In the early classes on the CCP (7,523 trainees, 112 months) the teaching concentrated on the history of the Party since its foundation, and on extolling the glories of the "Liberation". From 1953 onwards, these classes laid more stress on the Party line and its objectives as the 1950s were a time when a new economic strategy was being adopted. But from 1961 onwards, at a time when the tensions between Mao and the Party were more and more visible and when China had taken stock of the social and economic policies applied over the previous decade, trainees were supposed to think about "building" the Party. The classes on socialism $(3,605$ trainees, over seven years) were devoted to the basic principles of Marxist philosophy and the theories of socialism. We come lastly to the study of texts (950 trainees, four years), which were related either to contemporary political events, such as the Three Antis (Sanfan) studied in 1952 or to written accounts of Party meetings. However, starting in 1960, the Party school mainly had its students reading extracts from the selected works of Mao, which says a lot about the political 
context of the time. In consequence, the classes on the Chinese Communist Party occupied the predominant place, which after all is quite normal for a Party school.

\section{...to international finance}

41 Shortly after it reopened, at a time when China was committing itself to the path of reform, the classes at the Party school began a smooth transition. For the first courses, the works of Marx were on the syllabus, in equal place with those of Mao; little by little they were edged aside, making way for new subjects that were progressively introduced over the 1990s ${ }^{29}$. But the Party school waited until the Fifteenth Congress of the CCP in 1997 to definitively give up the study of Marxism and to introduce the theories of Deng.

The teaching of new subjects is in part taken on by the Administration Institute, which, as we have seen earlier, is responsible for all classes relating specifically to administrative science and its technical aspects. All new teaching not directly concerned with questions of public administration-that is, most of it-falls to the Party school. Subjects include law, management, human resources, economy and finance, and also international relations. Each of these new subjects is approached by way of topics as numerous as they are varied. They extend from the very general to the very particular, so as to cover the vast range of upheavals set in train by the reform policy and to help officials grasp these totally new situations.

Our survey, based on shared observation, reveals that classes on generalised topics, such as "the socialist market economy" or "the senior executive in the twenty-first century", mostly given by Party school lecturers, are regarded as rather boring by students. The most diligent among them take a few notes, but with little conviction; some others, Party officials though they are, openly read newspapers-and not necessarily the People's Daily; still worse, others play games on their mobile phones, which go beep-beep every time they win or lose; or they simply fall asleep at the back of the class, and snore. By contrast, classes based on case studies are what trainees most appreciate. Indeed, when a concrete question is to be studied, in its technical, financial or legal aspects (for example, "public construction and the property market"), the school frequently brings in an outside specialist, to whom it disburses a few hundred yuan in payment for two-and-a-half hours in the classroom. Not only does the specialist speak to his fellow-officials without that excessively professorial tone that the school's own lecturers adopt, he can share his own experience with them and discuss solutions they can apply to the problems they will have to face. Thus it was that a senior official of the Shanghai Municipal Administration found himself facing his opposite numbers from one of Shanghai's neighbouring provinces, listing in great detail the various redundancy schemes that the Municipal Administration was introducing following the closure of state enterprises. As it happened, the conclusion that the trainees drew from this session-highly instructive-was that the government of their province would not be able to apply the Shanghai solutions, for the very good reason that it was not as rich as Shanghai...

However, it is not just the content of the classes that has evolved. Since the start of the 1990s, the school has undertaken to modernise its teaching methods. To this end, it sent its teaching staff on various training courses, not only to teach them how to give PowerPoint presentations but also so that they could polish up their own competence 
in their specialised fields. They are also asked not to content themselves with speaking throughout their classes from the platform at the front of the room, as they had always done before, but to encourage debate, either by prompting trainees to ask questions, or by dividing the class into small groups so they could debate among themselves. At the end of each course, the trainees are handed round a questionnaire that they must fill in anonymously, and in which they must award a mark to each lecturer. Those lecturers who accumulate a certain number of bad marks are provisionally suspended from teaching while they undergo re-training.

The trainees themselves are put to the test in this new way of teaching. They can no longer be content with a passive act of attendance; they must take an active part in debates, hand in written work and take exams at the end of the course. Again, they have a strong interest in winning good marks, in order not to hold back their careers. While the main part of the course syllabus consists of lectures and seminars, there are several variations according to the age-groups of the trainees. The school divides trainees among three age-groups: junior officials (qing qingnian ganbu) aged between 24 and 34, young officials (zhong qingnian ganbu) from 34 to 44 , and lastly the senior officials aged 44 and above. Whereas this last category attends only lectures and seminars, the other two do fieldwork. The courses for the juniors last for eight months. They spend the first three within the People's Liberation Army then the next three working the land in the countryside; only the last two months are devoted to study. The officials aged from 34 to 44 do a three-month course ending with a week of fieldwork that is spent visiting other local administrations or-and this is a frequent alternative-attending classes at the Shenzhen Party School. Indeed, even though the Shanghai School enjoys its status as a model provincial Party school, it does recognise that the Shenzhen School has plenty to teach it, in particular because the big Special Economic Zone in the south entered the reform era well before Shanghai.

Moreover, the qualifications of the teachers at the school have also evolved. Before 1979, they were all theoreticians straight from the Party (dangnei lilun laoshi) whereas, since the reforms, the school has tried to recruit more among young university graduates at a level equivalent to a master's degree or, better still, a doctorate: such recruits are not easy to find. Indeed, almost all such graduates, on finishing their studies, aspire to a well-paid job in the economic sphere and the private sector. To those preferring to stay in the teaching milieu, numerous higher education establishments are open. The latter are in general more prestigious than the Party schools or the administration institutes (with the exception of the Central Party School and the Administration Institute in Peking, both enjoying a special aura that confers unequalled status) and can offer posts at a relatively comfortable level of pay with significant advantages. As a result, the teachers recruited by the Party schools at the local level are generally those who have not been able to find posts elsewhere.

However, there are some exceptions; and at the Shanghai Party School one of these is Wang Zhiping, who is regarded as a model. The latter joined the teaching staff of the school in 2000 to become economics professor, at a time when he was at the peak of his career, with the job of Director General of a big textile company and earning a salary of about 10,000 yuan a month. Wang took a master's degree and a doctorate from Jiaotong University, going on to hold various posts in business and the administration that took him several times to America; later on, he stayed there as a guest researcher. He is the only teacher in the school who has behind him twenty years' experience of the world of 
work-and this makes itself felt both in the content of his classes and in his teaching style. Although he now earns "only" 3,000 yuan monthly, he does not regret having made this career choice; it gives him job security, as well as a network of connections, and above all the free time to teach elsewhere, which includes MBA courses that pay between 500 and 1,000 yuan for a day's teaching. The work he does on the side enables Wang to double, even to treble, his monthly earnings...

The reform policy has thus had two important consequences. For one thing, the topics dealt with in the classes have been adapted to bring them into line with the new Chinese realities that the officials will have to confront; and, for another, the spirit of emulation, or even competition, has invigorated the teaching staff and the trainees. Admittedly, these changes help to distance the Shanghai Party School from what it started out to be, namely, a political school in which trainees were inculcated with a few notions of Marxism and much propaganda. Instead, they are gradually turning it into a modern institute of public administration, where the teaching has a direct application to the management of the city. From this point of view, one may say (in response to the question asked about the ambivalence of the changing content of the classes) that the Shanghai Party School is leaning towards making politics more professional. But there are limits.

Indeed, political propaganda is still omnipresent in all classes, even those which on the face of it concern only the technical aspects of administration. What is more, classes of a more political nature have not completely disappeared from the timetable, although they also have been spiced up to suit more modern tastes. This means that the political norms have changed as well. Control is still there. It is exerted by means of techniques that have developed, if not in step and in agreement with society, then at least in the direction of an overall change desired by the regime: Marx and Mao have been replaced by Deng who himself has given way to Jiang Zemin. It is true that political classes do not fill so much space today; of the nine classes a week that normally make up a fulltime course, two on average are clearly designed as propaganda. And in this respect, the Shanghai School is still unmistakeably the Party school. Moreover, while the trainees are encouraged to express themselves in written homework and to take part in debates, they must not stray outside the Party line. Thus, to a question that was used as the title for an essay, "What makes a good senior official?", if a trainee had replied, "a certain level of education" or "first and foremost, a sense of public welfare", the essay would have been marked down to zero ${ }^{30}$. The good senior official is first and last the one who follows the line of the Chinese Communist Party.

\section{The many faces of the Party school}

What is a Party school in present-day China? Our study has shown that it is valued more for the contacts (guanxi) that students can make there than for the teaching it offers. But we are also keen to show that the story of the Shanghai Party School has gone hand in hand with that of the Chinese communist regime. In a way, the school embodies the pulse of the Party-state. It is not just an indicator of its evolution but also a vital organ of its apparatus. 


\section{The pulse of the Chinese communist regime}

51 During that period when the regime's institutions were being formed, the qualifications of the school's recruits as well as the subjects it taught reflected the priorities of the Party-state. When the latter found itself weakened by the violence of the political campaigns and factional struggles of the Hundred Flowers Movement, and then by the Cultural Revolution, the Shanghai Party School-along with the various Party schools across the country-had to close down. And, since it reopened in 1978, the building of a larger and more modern campus, and the changes brought about in the recruitment of trainees and teachers, as well as the content of the courses and the teaching methods, may be taken as so many signs attesting to the modernisation of the school in step with that of the country.

However, the Shanghai Party School is much more than the mirror of the communist regime. Because a change of post is generally preceded by a training course, this school, like all the other Party schools, plays its part in the circulation of the Party-state's elite, that is to say, its senior executives, the very people who manage and direct the course of the reforms. The training course, because it enables senior executives to take stock of selected and specific questions relating to the reforms, can be useful for them in the performance of their duties and helps to professionalise their jobs.

\section{An instrument in the service of the Party-state}

53 But why should this further training be restricted to the Party schools and the administration institutes attached to them? After all, would they not suit structures other than those of the Party, such as universities and institutions for higher education and vocational training? The latter, in Shanghai as in other great Chinese cities, are offering an increasing number of complementary training programmes with diplomas thrown in, designed for people already in the employment market but wanting to resume their studies to reach a better understanding of this transition period. It is true that, for the time being, these programmes consist mainly of courses in languages, accountancy and management, or MBA courses-some of which, like that of the China Europe International Business School (CEIBS) are beginning to acquire some prestigeand as such do not directly address the needs of senior executives in the administration. For a start, local government (administration and human resource offices) would have to reach agreement with institutions of higher education on creating further training programmes specially tailored for working civil servants. By shifting in this way the training of Party-state officials towards educational structures outside those of the Party, Chinese leaders would be showing a real will to professionalise the executives. But that would require the Party-state to accept the loss of some small amount of control over its own life blood.

At the end of the 1990s, the Shanghai Normal University did set up a course of study in "administrative science" aimed at students who wished to study for a career in the administration. This innovation might have constituted an advance towards separating the career of state civil servant from that of Party official, which would have given full professionalism to the status of both. But on closer examination, the training is discovered to have been put in place on the initiative of the Shanghai Party School: it was seeking thus to renew its elite by selecting, at the end of the programme, the best 
students in order to add them to its own training group of junior officials aged 24 to 34 . Besides, some of the College's courses are held in the Party school. So there is no question of separating the training-and thus the duties-of state civil servants from that of Party officials, nor is there any question either of separating the structures of the state administration from the Party apparatus. Even Shenzhen, although it had promised reforms to its administration ${ }^{31}$, did not plan to go so far, despite what some of its more optimistic spirits were thinking ${ }^{32}$. When one considers that the Shenzhen Party School, which today is merged with its Administration Institute, will shortly be moving to a bigger campus while continuing to house the Administration Instituteand all this despite the restructuring of its own administration-one cannot envisage any possible separation between the Party and the state in a city that, like Shanghai but in different respects-is at the cutting edge of the economic reforms. For the separation to be effective, it would have to separate the training of civil servants in the administration from that of officials in the Party. And, as has already been emphasised, the courses given in the Party schools are also designed to ensure regular control over the officials' level of political instruction and to make sure that its elite continues to think and act in step with the Party line. Because they help to maintain the dominance of the Party-state in China, the Party schools are a vital mechanism in perpetuating the regime.

\section{...or an agent for change?}

However, the relationship between the Party-state and its schools is not a one-way transaction, in which the former uses the latter as an instrument in the exercise of its power. It is common knowledge that the Central Party School organises discussions and debates that are relatively open as to the line to be adopted by the Party and the way in which the reforms should be carried forward. In this context, the Central Party School is rated as a think tank in the network of Peking's top advisers even though there are doubts as to its real influence over the policies implemented ${ }^{33}$. What matters is that it takes part in one way or another in the decision-making process, and reflects the evolution of the Party-state while not actually reforming it. To a lesser extent, the local Party schools are also the think tanks of the local authorities, advising them on more contextual aspects of introducing and managing the reforms and, in doing so, they also take part in redefining the role of the Party-state in the reforms.

So there are two views of reality and two approaches still to the question of what developments may be possible. For the time being, while the Party schools are not the agents of radical change, they do nevertheless appear to be the agents of some lesser form of change in a scheme that is more social and cultural than political; thus, they help to perpetuate a system of domination. The changes, now and always, are inspired pragmatism; and they are nothing less than a new attempt to legitimise the old system. 


\section{NOTES}

1. This study, the result of a fifteen-month stay in Shanghai, was made possible thanks to the financial support of, firstly, the French Ministry of Foreign Affairs, which awarded me the Lavoisier Scholarship (2000-2001) and, secondly, the Centre d'études français sur la Chine contemporaine (CEFC) in Hong Kong where I am grant-holder (2001-2003). I should like to express here my heartfelt gratitude to those who have supported my candidacy for both these grants of financial help

2. Andrew Nathan and Bruce Gilley, China's New Rulers: The Secret Files, Granta Books, London, 2002. The Chinese-language book on which they based their work is by a Chinese national who is particularly well informed about the internal affairs of the Party and who has had access to unpublished documents (in this case, draft reports from the Department of Organisation), which well-placed correspondents in Peking had sent to him personally: he is Zong Hairen, Disidai (The Fourth Generation), Mirror Books, New York, 2002

3. This eventuality was mentioned for the first time only two days before the opening of the Sixteenth Party Congress in a Hong Kong newspaper: "Zhengzhi ju changwei zeng zhi 9 ren": ("The Permanent Committee of the Politburo enlarged to nine members"), Mingpao, November 7th 2002, p. A2

4. Stéphanie Balme (Mutation du communisme et crise de l'Etat néo-patrimonial en Chine : enquête sur le népotisme et les guanxi dans la sélection de l'élite dirigeante (1978-1997), thesis for the Paris IEP, December 2000) deals with the question of the professionalisation of the regime's elite officials, particularly in part 3. Her approach is from a general perspective, rather than the localised one that we are attempting here.

5. I owe the opportunity of this fieldwork to Nicolas Chapuis, France's Consul-General in Shanghai at that time, to whom I should wish to express here my deepest thanks. His support was decisive in persuading the management of the Shanghai Communist Party School to allow me to carry out this study under favourable conditions. Indeed, I joined the school as a trainee on the same basis as the Party's other trainees; this represented a first, not just for the school but also for someone who is neither a member of the CCP nor a national of the People's Republic of China 6. When the school was founded, in June 1949, it was located in the French concession at 535, Fahuazhen lu. Then, in February 1959, it moved to the former premises of the Aurora University, which today houses the Shanghai Academy of Social Sciences, at 622 Huaihai lu. During the Cultural Revolution, the school-although it had ceased all activity-maintained an office and a postal address in Jiaotong University. Lastly, when it reopened on April 11th 1978, it occupied premises that are today those of the Shanghai Normal University (Zhonggong Shanghai shiwei dangxiao zhi,) Shanghai, Shanghai jiaoyu chubanshe, 1999, pp. 1, 7 and 12.

7. Ibid. p. 17

8. Ibid. At the time of writing, this is the only written and, presumably, official reference to the cost of building the school and its campus. However, during my numerous interviews with various managers of the establishment, they gave far higher figures, rising as high as 200 million yuan! Even admitting an element of exaggeration in their replies-motivated perhaps by a wish to emphasise the importance of the project and the priority accorded it, as well as by their pride in belonging to a place that cost so much-one may nevertheless believe that the initial budget, which was fixed at 37 million yuan, was exceeded

9. Interview with the Director of the Institute of Sociology at the Shanghai Academy of Social Sciences.

10. Zhonggong Shanghai..., op. cit., 1999, p. 1.

11. Ibid., p. 47 
12. Ibid., p. 110

13. Ibid., p. 111

14. From the 8,533 trainees (not counting the 800 workers who had their own school), who passed through the Party school before 1959, we have deducted the 1,040 seamen

15. "Guanyu lunxun quan dang gao, zhongji ganbu he tiaozheng dangxiao de jihua" (Plan for training all the senior and middle-ranking officials of the Party and for readjusting the Party schools), published by the central CCP, December 17th 1954

16. Zhonggong Shanghai..., op. cit., 1999, pp. 10-11

17. Marie-Claire Bergère, La République populaire de Chine de 1949 à nos jours, Paris, Armand Colin, 1987, pp. 126-128, and, by the same writer, Shanghai, Paris, Fayard, 2002, pp. 414-426.

18. Zhonggong Shanghai..., op. cit., 1999, pp. 108-112.

19. On this subject, see the further analysis done by Jean-Pierre Cabestan, Le système politique de la Chine populaire, Paris, PUF, 1994, "L'institutionalisation avortée du régime (1949-1957)", pp. $115-128$

20. Shanghai, op.cit., 2002, p. 428

21. Zhonggong Shanghai..., op. cit., 1999, p. 36

22. Zhiyue Bo, "The Provinces: Training Ground for National Leaders or a Power in Their Own Right?", in David M. Finkelstein and Maryanne Kivlehan eds., China's Leadership in the 21st Century: The Rise of the Fourth Generation, New York, M.E. Sharpe, 2003, pp. 66-117

23. "Guanyu shixian dangxiao jiaoyu zhengguihua de jueding" (Decision concerning the establishment and regularisation of education in the Party schools), CCP Central Committee, May 1983

24. "Quanguo ganbu peixun guihua yaodian" (The main points of the national plan for training officials), Department of Organisation, October 1983. This document asks the provinces and the city administrations whose authority derives directly from Peking, as well as the autonomous regions, to create administration institutes (xingzheng guanli xueyuan).

25. For an overall study on the modernisation of Chinese administration, cf. Jean-Pierre Cabestan, L'Administration chinoise après Mao :les réformes de l'ère Deng Xiaoping et leurs limites, Paris, Editions du CNRS, 1992

26. "Guanyu jianli zaizhi juji ganbu xuexi zhidu de tongzhi" (Note on bringing about the system of study for officials working in the departments), Shanghai CCP, May 5th 1990.

27. Definition taken from the Petit Robert dictionary

28. These figures are arrived at by compiling data published in Zhonggong Shanghai..., op. cit., 1999, pp. 108-130

29. The introduction of new subjects in the Party schools has been explained by Jean-Pierre Cabestan, Le Système politique, op.cit., pp. 412-413

30. This anecdote is based on my personal experience. In this exercise, given to us right at the beginning of the training course, all the trainee officials in my class, except for me, mentioned that the first quality required of a senior official was to conform to the Party line, before going on to other qualities that they thought were as important or even more important. Of course, they all received good marks, whereas in my case it was kindly explained that an essential quality was missing from the list I had made, a quality without which one could not be a good official.

31. Dagongbao, December 20th 2002

32. Mingbao, December 20th 2002; Nanfang Zhoumo, December 19th 2002; Financial Times, January 13th 2003

33. Cf. Joseph Fewsmith, "Where Do Correct Ideas Come From? The Party School, Key Think Tanks and the Intellectuals", in David M. Finkelstein and Maryanne Kivlehan eds., op. cit., pp. 152-164. 